\title{
Insect emergence in Canadian coldwater springs: spatial and temporal patterns, and species-environment relationships
}

\author{
F.O. Gathmann, D.D. Williams*
}

Surface and Groundwater Ecology Research Group, Department of Life Sciences, University of Toronto at Scarborough, 1265 Military Trail, Scarborough, Ontario, Canada M1C 1A4.

Considerable spatial and temporal variability was detected in the environmental conditions in 30 coldwater springs in southern Ontario, Canada. Using standard pyramidal emergence traps, a total of 86 insect species was recorded from these springs (not including the Chironomidae). These represented nine taxonomic groups, among which the Limoniidae (Diptera) was the most diverse with 38 species. Fifty-five per cent of all species recorded had a low frequency (found at three or fewer sites), and only for very few of these rare species were more than 10 individuals $\mathrm{m}^{-2}$ collected. Interannual differences were also apparent. Continuous sampling over time showed that emergence records from a single year, on average, contained only around $50 \%$ of the total number of species obtained during the entire study. Species-environment relationships analyzed by Canonical Correspondence Analysis indicated that temperature and discharge correlated most strongly with insect community similarity among spring sites. The prospects for developing regional typologies of coldwater springs, based on their environmental conditions, and the implications of species loss to the continuity of function of coldwater spring ecosystems are discussed.

Keywords: coldwater springs, species-environment relationships, insect emergence, Limoniidae

\section{Introduction}

Coldwater springs are unique habitats, chiefly characterized by transition zones between several radically different environments. Along the longitudinal axis, a typically stable body of groundwater is gradually replaced by a highly dynamic headwater stream (Williams 1991). This transition is typically reflected by pronounced changes in water chemistry and physiography, such as an increase in dissolved oxygen concentration and annual temperature amplitude (Kamp 1995, McCabe 1998). Perpendicular to this longitudinal gradient, coldwater springs show the same transition from aquatic to terrestrial conditions that characterizes many other freshwater systems. However, due to the restricted size of most springs, the semi-aquatic/terrestrial habitats in this ecotone typically constitute a much larger fraction of the total available habitat than in other running waters (see also Fischer et al. 1998).

The heterogeneous patchwork of microhabitats created by these two orthogonal environmental gradients supports diverse spring floras and faunas. A significant fraction of the species found in coldwater springs either do not occur elsewhere or prefer springs over other aquatic habitats (crenobiont and crenophilous species, respectively). These springdependent species increase the overall species diversity of a river catchment, particularly for certain taxonomic groups (e.g., Trichoptera and Diptera; Erman \& Erman 1995).

The spatial heterogeneity of coldwater spring habitats is in stark contrast to the image of their temporal uniformity purported in most of the classical ecological literature (e.g., Odum 1971). Indeed, most of the springs studied in the early days of crenobiology were large rheocrenes (flowing springs; see Danks \& Williams 1991), showing very little variation in either physical or chemical conditions (e.g., Odum 1957, Tilly 1968). However, more recent studies focusing on the physiography of springs (van Everdingen 1991, Kamp 1995), as well as a number of faunistic surveys from Europe and North America, paint a much more diverse picture of the temporal dynamics of coldwater springs. In particular, springs fed by shallow and nearsurface groundwater systems are now known to show pronounced seasonal fluctuations in discharge and temperature (van Everdingen 1991). Moreover, depending on the topography of the spring valley, even large, seasonally stable springs can exhibit sudden changes in discharge and temperature following snowmelt or heavy rain (Fischer et al. 1998).

The last decade or so has witnessed a surge of interest in springs among ecologists, culminating in two symposia (Williams \& Danks 1991, Ferrington 1995) and a monograph (Botosaneanu 1998) on crenobiology. There are three main lines of motivation behind

* Corresponding author : E-mail: williamsdd@utsc.utoronto.ca

Article available at http://www.limnology-journal.org or http://dx.doi.org/10.1051/limn/2006015 
this work (Williams \& Williams 1998). First, certain spring types - namely, the 'classical' rheocrenes mentioned above, with their stable environmental conditions - are ideally suited to study current topics of pure ecology such as trophic links in communities (Iversen 1988) or ecophysiology (Glazier 1998). Second, spring organisms are valuable as water quality indicators for groundwater monitoring purposes (Williams 1991). Finally, due to their particular habitat conditions, coldwater springs are also of considerable biogeographical interest as refuges for relict species (e.g., Nielsen 1950).

In this paper, we present the results of a comparative faunistical survey of 30 coldwater springs in southern Ontario, Canada. The main objectives were to further our knowledge on the environmental characteristics and faunistic inventory of North American coldwater springs, and to investigate which environmental factors are most influential in shaping insect community composition at spring sites. We also report observations on frequencies and abundance patterns of the recorded insect species and compare species richness at the sites covered by the survey.

\section{Methods}

\section{Study area}

Thirty coldwater spring sites from southern Ontario, Canada, were included in this survey. The majority of the study sites are located in or near an area known as the Oak Ridges Moraine (Fig. 1: Groups A to F and J, comprising a total of 21 springs). The Oak Ridges Moraine, extends for more than $200 \mathrm{~km}$ parallel to the northern shore of Lake Ontario. It was formed as an interlobate moraine when the last glacier receding from southern Ontario split into a southern and northern lobe approximately 15,000 years ago, and large meltwater streams deposited enormous quantities of glacial debris in the open crevasse. Up to $15 \mathrm{~km}$ wide and in some places more than $200 \mathrm{~m}$ thick, the glacio-fluvial deposits forming the Oak Ridges Moraine today serve as the largest groundwater reservoir in southern Ontario, and give rise to most of the important rivers in the region (Liberty 1969, STORM Coalition 1997). This abundance of groundwater has resulted in an exceptionally high density of coldwater springs across large parts of the moraine. To extend the geographical scope of the survey, another group of study sites (Fig. 1: Group O, 9 springs) was selected further north in the Bass Lake kame moraine located in Oro Township, near the northwestern shore of Lake Simcoe. The Bass Lake kame moraine shares with the Oak Ridges Mo- raine a glacio-fluvial origin at the end of the Pleistocene Era (Deane 1950).

Both the Oak Ridges and the Bass Lake kame Moraine have undergone extensive re-forestation after a period of extensive logging in the $19^{\text {th }}$ Century. They thus represent secondary growth areas as undisturbed as it is now possible to find in southern Ontario, and their spring faunas are likely to reflect natural species richness levels.

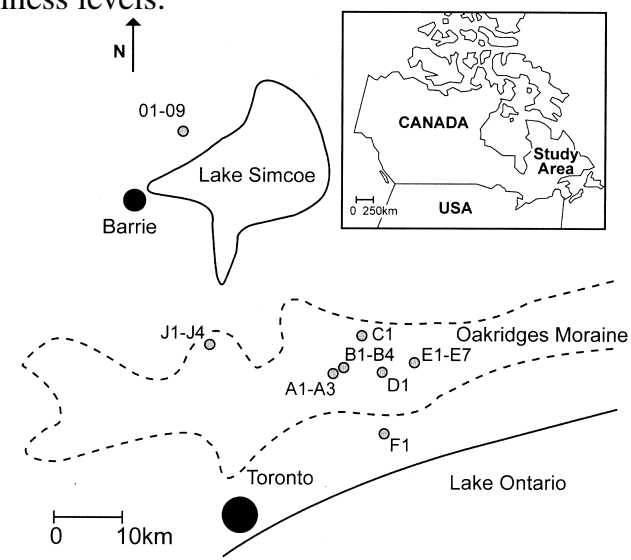

Fig. 1. Map of the study area showing the two groups of study springs, one along the Oakridges Moraine $\left(44^{\circ} 00^{\prime} \mathrm{N} ; 79^{\circ} 15^{\prime} \mathrm{W}\right)$, the

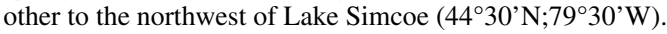

Table 1. Characteristics and locations of the study sites (Eastings and Northings relate to Universal Transverse Mercator Geographic Coordinate System [UTM] Grid Zone 17; NAD = North American Datum Base).

\begin{tabular}{lllll} 
Site & Spring type & Easting & Northing & Base \\
\hline & & & & \\
A1 & Limnocrene & 635550 & 4871100 & NAD83 \\
A2 & Rheo-limnocrene & 635500 & 4871150 & NAD83 \\
A3 & Helocrene & 635550 & 4871250 & NAD83 \\
B1 & Helocrene & 637250 & 4871950 & NAD83 \\
B2 & Helocrene & 637300 & 4872000 & NAD83 \\
B3 & Rheo-limnocrene & 637250 & 4872150 & NAD83 \\
B4 & Limnocrene & 637150 & 4872000 & NAD83 \\
C1 & Limnocrene & 641850 & 4879400 & NAD27 \\
D1 & Helocrene & 646350 & 4871450 & NAD27 \\
E1 & Limnocrene & 653250 & 4873650 & NAD27 \\
E2 & Helo-rheocrene & 653400 & 4873750 & NAD27 \\
E3 & Helocrene & 653500 & 4873800 & NAD27 \\
E4 & Rheocrene & 653600 & 4873850 & NAD27 \\
E5 & Rheocrene & 653850 & 4873900 & NAD27 \\
E6 & Helocrene & 654000 & 4873900 & NAD27 \\
E7 & Helo-rheocrene & 654000 & 4873800 & NAD27 \\
F1 & Rheocrene & 646750 & 4857400 & NAD83 \\
J1 & Helocrene & 618050 & 4876050 & NAD27 \\
J2 & Rheocrene & 618200 & 4876100 & NAD27 \\
J3 & Helocrene & 618450 & 4876150 & NAD27 \\
J4 & Helocrene & 618800 & 4876050 & NAD27 \\
O1 & Limnocrene & 613750 & 4935000 & NAD83 \\
O2 & Limnocrene & 613450 & 4935050 & NAD83 \\
O3 & Rheocrene & 613050 & 4934950 & NAD83 \\
O4 & Helo-rheocrene & 613050 & 4935150 & NAD83 \\
O5 & Helocrene & 612800 & 4934850 & NAD83 \\
O6 & Helo-rheocrene & 612050 & 4934750 & NAD83 \\
O7 & Helocrene & 611900 & 4934950 & NAD83 \\
O8 & Helocrene & 611900 & 4935150 & NAD83 \\
O9 & Helocrene & 612200 & 4935150 & NAD83 \\
& & & & \\
\hline & & & & \\
\hline
\end{tabular}


The majority of sites were selected so as to form groups of spatially neighbouring sites, and to ensure that they adequately reflected the locally available spectrum of physiographic spring types. This we assumed would yield an accurate picture of the insect diversity in each area (Table 1). The type of spring was based on the classical designation of limnocrenes, helocrenes, and rheocrenes (see Danks \& Williams 1991), with some hybrids (e.g., 'Helo-rheocrene': where groundwater water arising through a mat of vegetation subsequently flowed over a substrate of sand or fine gravel). All limnocrenes and helocrenes were less than $2 \mathrm{~m}$ in diameter, and the rheocrenes less than $1 \mathrm{~m}$ in width.

\section{Sampling regime}

Sampling occurred from spring of 1996 to autumn of 1998. However, not all sites were sampled at all times and with the same frequency. In 1996, 26 sites were sampled at two-week intervals (Groups A to F, and O; Fig. 1). In 1997, another group of sites (Group J) was added, and sampling frequency was reduced to monthly intervals. Finally, for logistical reasons, in 1998, only three of the sites from 1996 (E1, E3, and O8) and the sites of Group J were retained in the sampling programme. Due to winter accessibility problems, no samples were taken in January and February of 1997 and 1998. The change from two-week to monthly emptying of the collection jars was required for logistical reasons, but as the numbers of insects obtained were cumulative this adjustment is unlikely to have introduced any sampling bias over time.

\section{Sampling of abiotic factors}

Measurements of $\mathrm{pH}$, conductivity, and percent oxygen saturation were obtained with a $\mathrm{H}_{2} \mathrm{O}$ multiprobe (HydroLab Corp., Texas). Measurements were taken each time from the same spot, as close to the source of the spring as possible. From early 1997 to early 1998 , temperature was monitored at 20-minute intervals using electronic HOBO loggers (Onset Corp., California). Discharge was estimated with the floating object method (Gore 1996) each time insect collections were made.

\section{Sampling of insect emergence}

As the springs were small, emerging insects were trapped with standard pyramidal traps covering an area of $1 \mathrm{~m}^{2}$ (Mundie 1956). At each spring, a single trap was carefully placed so as to ensure that all of the microhabitat types visible at each site were covered, but also allowing open areas so as to prevent destructive sampling of populations. The traps sampled continuously between collection times, with glycol used as a killing and preservation liquid. Comparing emergence sampling and benthos sampling in coldwater springs, Erman (1998) found that the former generally detected more species than the latter. However, hololimnic species are not represented in emergence samples at all, and recorded abundances have to be treated with some caution, as they do not always correlate well with larval abundances. For instance, some larvae migrate away from the trap for pupation (Wagner et al. 1998), and spiders can be very effective in reducing the number of adults that make their way into the trapping jar (F.O. Gathmann, pers. field observations). Poor representation of beetles also may result from this collection technique (Roughley \& Larson 1991).

Upon collection, recovered specimens were transferred to $70 \%$ ethanol for final preservation, and the traps were re-set. Using available taxonomic literature and the generous assistance of several specialists, specimens were identified to the lowest practical taxon, which was usually species. However, in order to concentrate taxonomic effort on some of the lesser-studied taxa (especially the Limoniidae) in coldwater springs, we decided to forego identification of the numerically dominant Chironomidae beyond the family level. An analysis of chironomids in Canadian coldwater springs is given in Colbo (1991).

\section{Statistical analyses}

Species-environment relationships were examined using Canonical Correspondence Analysis (CCA, ter Braak 1986) as implemented in the PyDAS package for multivariate statistical data analysis (Gathmann 2000). Because the variability of an environmental factor over time is as important in determining the response of a particular species as is the mean value, we computed both mean values and coefficients of variation (i.e., the standard deviation divided by the mean) from the field data for each of the five recorded environmental parameters (temperature, discharge, $\mathrm{pH}$, conductivity, and oxygen saturation), and for each site. Linear regression analyses were done, where appropriate, to explore individual species-environment relationships, such as number of species against mean spring discharge.

For the adult insect data set, log-transformed abundance data were used from a subset of the emergence data set based on the longest common sampling period at all sites. Because of the large uncertainty associated 
with records for species with very low abundances, species for which fewer than 5 individuals had been collected were discarded. Similarly, as species with very high frequency are known to contribute only marginally to the resulting ordination plot, we also discarded all species which occurred in 25 or more of the 30 sites. With these reductions, the final faunistic data set retained a total of 55 species.

\section{Results}

\section{Abiotic data}

Figure 2 summarizes the results of the abiotic sampling programme. For a comparison of these results among sites we consider the spatial and temporal components of the variability in the data separately.

\section{Spatial variability}

Among the five abiotic parameters measured at the sampled sites, mean water temperature showed the lowest variability (Fig. 2a). The only obvious trend was a drop of about 1.1C from the Oak Ridges Moraine sites further north to the Oro sites, which closely matched the difference in mean annual air temperature in these two regions. Mean discharge, on the other hand, was extremely variable among sites (Fig. 2b), with larger limnocrenes and rheocrenes exceeding the values shown by smaller helocrenes by up to two orders of magnitude. The mean values of the remaining three parameters, $\mathrm{pH}$, oxygen saturation, and conductivity (Figs 2c-e), revealed no clear large-scale pattern. However, visual inspection of the means within a group of spatially adjacent sites were not necessarily more similar to each other than to means of any site from other groups, suggesting high within-group (small-scale) variability. Oxygen saturation showed the most, and conductivity the least, within-group variability.

\section{Temporal variability}

In contrast to the evenness of the annual water temperature means among sites, the variability of temperature over time differed markedly within sites (see ranges on Fig. 2a). Whereas larger limnocrenes and rheocrenes - the 'classic' springs - showed almost no change in temperature over the full year of temperature monitoring (e.g., sites A1, A2, and E1), some of the smaller helo- and rheocrenes exceeded temperature amplitudes of 10C (e.g., sites B2, J4, and O9). The data support a strong negative relationship between mean discharge and temporal variability in water temperature

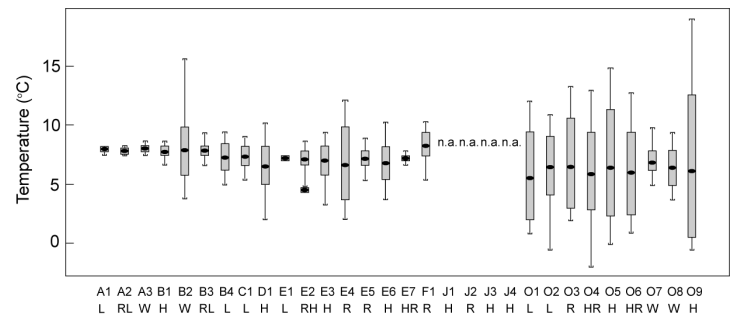

(a) Temperature
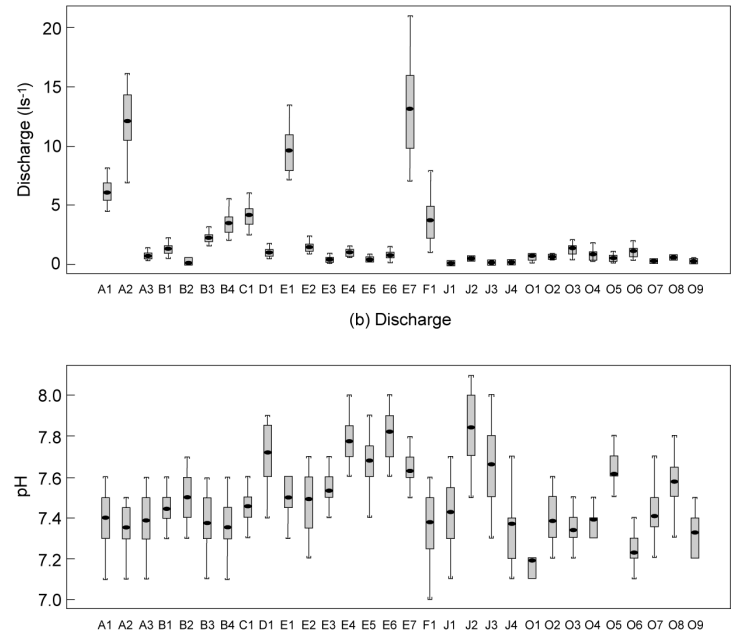

(c) $\mathrm{pH}$
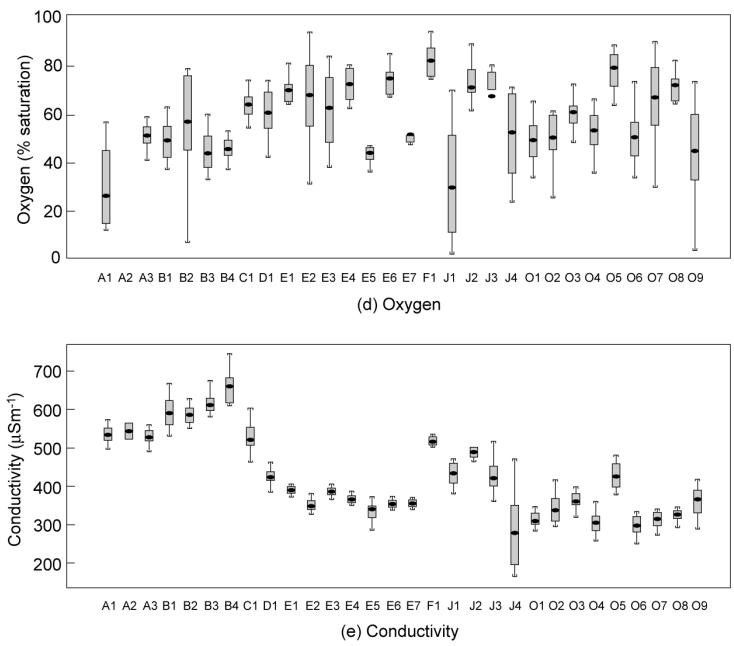

Fig. 2. Boxplots of the abiotic parameters measured in each of the 30 springs studied, over time (black dots indicate longterm means, rectangles indicate median values, t-bars represent ranges, 'n.a.' indicates datalogger malfunction). Abbreviations indicate the type of spring (see Table 1): $\mathrm{L}=$ limnocrene; $\mathrm{RL}=$ rheo-limnocrene; $\mathrm{H}$ $=$ helocrene; $\mathrm{HR}=$ helo-rheocrene; $\mathrm{R}=$ rheocrene.

(Pearson product-moment correlation coefficient: $\mathrm{r}=-0.53, \mathrm{p}<0.005, \mathrm{n}=26$ ), which is readily explained 
by the decreasing effect of extreme air temperatures on larger, faster moving bodies of surfacing, temperatureconstant groundwater. The distribution of discharge measurements shows a more or less pronounced skewness towards low-flow conditions at most sites. Although discharge estimates obtained with the floating object method are somewhat crude, the regular pattern found is not likely to have been caused by measurement errors. Rather, the bias in the data is a reflection of the brief peak in runoff reached during snowmelt in spring. Note, however, that for some of the smaller helocrenes, the most extreme outliers were recorded during summer, shortly after heavy precipitation.

\section{Taxon list}

The nomenclature, the frequency (i.e., proportion of sites at which a taxon was found), and the total number of individuals collected in the survey are shown in Table 2. A total of 86 species and 3 higher-level taxa are listed. Thirty-eight (44\%) species were contributed by the dipteran family Limoniidae alone, 19 species (22\%) by Trichoptera, and $9(10 \%)$ by Plecoptera. The number of Limoniidae species recorded in this study is likely to increase even further when the last taxonomic uncertainties are resolved (at least two species appear to be new to science; F. Brodo, pers, comm.).

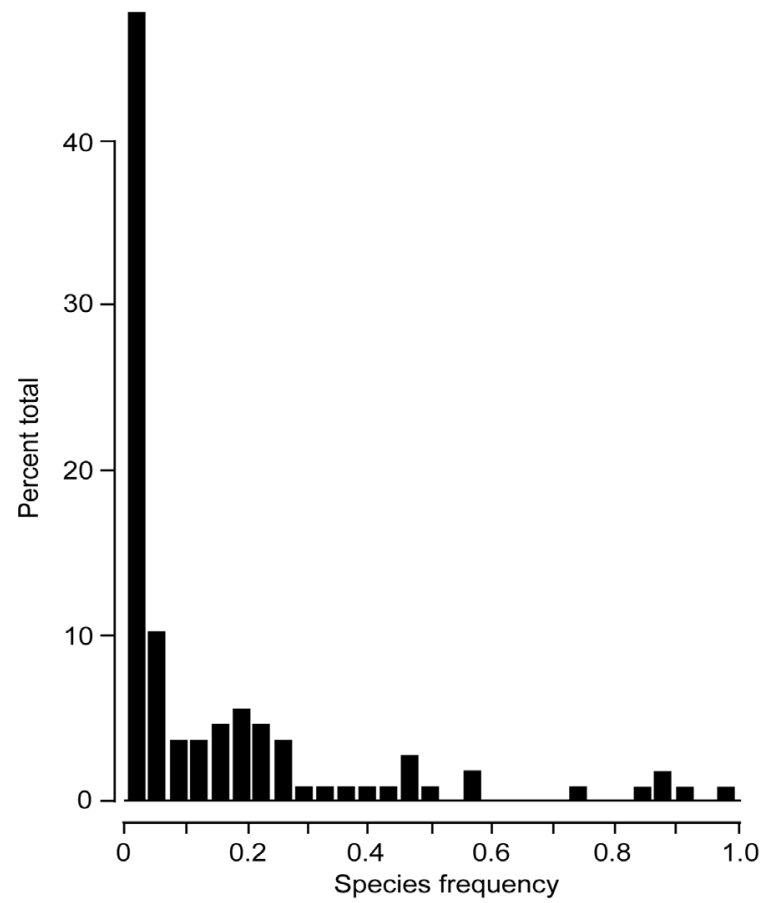

Fig. 3. Histogram of species occurrence frequencies in samples from the 30 springs.

\section{Species frequency}

The frequency data in Table 2 (represented graphically in Fig. 3) show a very strong prevalence of rare species: over $35 \%$ of all species occurred at only one of the 30 sites, over $45 \%$ at one or two sites, and over $55 \%$ at one to three sites. At the other end of the frequency spectrum, the four most frequent species were the limoniid Dicranota flaveola (0.93), the plecopteran Nemoura trispinosa (0.9), the trichopteran Lepidostoma sp.1 (0.9), and the dixid Dixa similis (0.87).

\section{Species abundance}

The column listing maximal local abundances in Table 2 indicates that very few species were present in local populations exceeding 50 individuals $\mathrm{m}^{-2}$ in any given year. Although these high-abundance species were usually also widespread (their average frequency amounts to 0.54), their maximal local abundance often represented a large fraction of the total number of collected individuals (on average, 26\%), indicating a strong preference for individual sites. For the rare species ( $\mathrm{f} \leq 0.1$ in Table 2), on the other hand, local population density exceeded 10 individuals $\mathrm{m}^{-2}$ in very few instances (e.g., for the plecopteran Nemoura albidipennis). Ranked abundances of all taxa (except Chironomidae n.det) at sites E1, E3, and O8 are shown for the three consecutive study years (Fig. 4). The rank of a particular taxon was determined from its average abundance over the whole study period, which is shown in the left-hand plots.

The annual rank-abundance plots show that at all three sites, a few species of medium to high abundance were associated with a large number of species of low to very low abundance. Comparing the rank-abundance plots for each site over time reveals that, although the general shape of the plots is preserved, there are considerable differences in the abundances of individual taxa among years. A particularly important aspect of this large variability in local abundances is that, in any given year, a number of species do not show up in the emergence record at all, although they are present in other years. Evidently, the probability of a particular taxon being absent is positively related to its rank (and inversely related to its mean abundance), but in some cases even taxa that show medium abundance levels in one year were missing in the next. Table 3 quantifies this effect. Even if we assume that the cumulative number of species after the full study period of three years represents the total number of species present which is likely over optimistic, as in all three sites new species were found in the last, 1998 season - on average 
Table 2. List of taxa: $\mathrm{f}=$ frequency of taxon; $\mathrm{N}=$ total number of individuals trapped at all sites; Nmax = highest local abundance, expressed as trapped individuals per site (i.e., per $\mathrm{m}^{2}$ ) per year; $\mathrm{n}$. det. indicates that further identification was not determined.

\begin{tabular}{|c|c|c|c|c|}
\hline Taxon & & $\mathbf{f}$ & $\mathbf{N}$ & $\operatorname{Nmax}$ \\
\hline \multicolumn{5}{|l|}{ Diptera } \\
\hline Ceratopogonidae & Ceratopogonidae $n$. det & 0.27 & 17 & 6 \\
\hline Chironomidae & Chironomidae $n$. det. & 1 & 14830 & 1041 \\
\hline \multirow[t]{4}{*}{ Dixidae } & Dixa inextricata Dyar \& Shannon & 0.23 & 42 & 11 \\
\hline & Dixa similis (Johannsen) & 0.87 & 598 & 45 \\
\hline & Dixa sp.1 & 0.1 & 6 & 3 \\
\hline & Dixella naevis Peus & 0.03 & 1 & 1 \\
\hline Dolichopodidae & Dolichopodidae $n$. det. & 0.5 & 92 & 45 \\
\hline \multicolumn{5}{|c|}{ Empididae } \\
\hline Hemerodromiinae & Chelifera caligae La Valee & 0.2 & 15 & 7 \\
\hline Clinoceratinae & Hydrodromia aff. binotata & 0.03 & 7 & 7 \\
\hline \multicolumn{5}{|l|}{ Limoniidae } \\
\hline \multirow[t]{12}{*}{ Eriopterinae } & Erioptera (Erioptera) megaophthalma Alexander & 0.23 & 9 & 2 \\
\hline & Erioptera (Erioptera) septemtrionis O.S. & 0.03 & 5 & 5 \\
\hline & Erioptera sp. 1 & 0.07 & 6 & 5 \\
\hline & Gonomyia sp. 1 & 0.07 & 9 & 7 \\
\hline & Gonomyia sp. 2 & 0.03 & 2 & 2 \\
\hline & Molophilus (Molophilus) cramptoni Alexander & 0.6 & 272 & 61 \\
\hline & Molophilus (Molophilus) fultonensis Alexander & 0.07 & 5 & 3 \\
\hline & Ormosia (Ormosia) romanovichiana Alexander & 0.03 & 1 & 1 \\
\hline & Ormosia (Parormosia) cf. nigripila O.S. & 0.43 & 172 & 62 \\
\hline & Ormosia (Scleroprocta) cf. innocens (O.S.) & 0.27 & 42 & 13 \\
\hline & Symplecta cana (Walker) & 0.03 & 1 & 1 \\
\hline & Tasiocera (Dasymolophilus) ursina (O.S.) & 0.03 & 1 & 1 \\
\hline \multirow[t]{18}{*}{ Hexatominae } & Eloeophila johnsoni (Alexander) & 0.03 & 6 & 6 \\
\hline & Eloeophila solstitialis (Alexander) & 0.17 & 12 & 6 \\
\hline & Euphilidorea caudifera (Alexander) & 0.23 & 10 & 3 \\
\hline & Euphilidorea similis (Alexander) & 0.03 & 1 & 1 \\
\hline & Hexatoma (Eriocera) breviorcornis (Alexander) & 0.07 & 6 & 3 \\
\hline & Limnophilia (Dicranophragma) fuscovaria (O.S.) & 0.1 & 4 & 2 \\
\hline & Limnophilia (Lasiomastix) macrocera Say & 0.07 & 2 & 1 \\
\hline & Limnophilia (Lasiomastix) subtenuicornis (Alexander) & 0.1 & 12 & 10 \\
\hline & Limnophilia (Lasiomastix) tenuicornis (O.S.) & 0.27 & 35 & 10 \\
\hline & Limnophilia (Arctolimnophila) subcostata Alexander & 0.03 & 10 & 10 \\
\hline & Neolimnomyia (Brachylimnophila) brevifurca (O.S.) & 0.27 & 29 & 6 \\
\hline & Paradelphomyia americanus (Alexander) & 0.53 & 228 & 32 \\
\hline & Paradelphomyia pleuralis (Dieta) & 0.5 & 143 & 19 \\
\hline & Pilaria quadrata (O.S.) & 0.07 & 3 & 2 \\
\hline & Pilaria tenuipes (Say) & 0.03 & 1 & 1 \\
\hline & Pseudolimnophila contempta (O.S.) & 0.1 & 479 & 138 \\
\hline & Pseudolimnophila luteipennis (O.S.) & 0.03 & 4 & 4 \\
\hline & Ulomorpha pilosella (O.S.) & 0.3 & 20 & 4 \\
\hline \multirow[t]{2}{*}{ Limononiiae } & Dicranomyia fusca Meigen & 0.03 & 1 & 1 \\
\hline & Dicranomyia humidicola O.S. & 0.17 & 5 & 1 \\
\hline \multirow[t]{4}{*}{ Pediciinae } & Dicranota (Rhaphidolabina) flaveola (O.S.) & 0.93 & 2254 & 375 \\
\hline & Dicranota (Rhaphidolabis) cayuga (Alexander) & 0.3 & 24 & 8 \\
\hline & Dicranota (Rhaphidolabis) forceps (Alexander) & 0.1 & 10 & 6 \\
\hline & Dicranota (Rhaphidolabis) tenuipes (O.S.) & 0.07 & 23 & 8 \\
\hline
\end{tabular}


Table 2. (Continued)

\begin{tabular}{|c|c|c|c|c|}
\hline \multicolumn{2}{|l|}{ Taxon } & \multirow{2}{*}{$\begin{array}{c}\mathbf{f} \\
0.1\end{array}$} & \multirow{2}{*}{$\begin{array}{l}\mathbf{N} \\
5\end{array}$} & \multirow{2}{*}{$\frac{N \max }{3}$} \\
\hline & Dicranota sp.1 & & & \\
\hline & Pedicia albivitta Walker & 0.6 & 81 & 15 \\
\hline & Pedicia contermina Walker & 0.2 & 15 & 4 \\
\hline & Tricyphona calcar (O.S.) & 0.07 & 4 & 2 \\
\hline & Tricyphona inconstans (O.S.) & 0.1 & 21 & 12 \\
\hline & Tricyphona vernalis (O.S.) & 0.23 & 14 & 4 \\
\hline Psychodidae & Neoarisemus niger & 0.1 & 3 & 1 \\
\hline \multirow[t]{6}{*}{ Psychodinae } & Clytocerus americanus (Kincaid) & 0.03 & 1 & 1 \\
\hline & Psychoda sp.1 & 0.07 & 5 & 4 \\
\hline & Telmatoscopus quadripunctatus (Banks) & 0.03 & 3 & 3 \\
\hline & Thornburghiella slossoni (Williston) & 0.2 & 74 & 13 \\
\hline & Threticus bicolor (Banks) & 0.1 & 11 & 4 \\
\hline & Tinearia alternicula (Quate) & 0.03 & 1 & 1 \\
\hline Ptychopteridae & Ptychoptera rufocincta O.S. & 0.33 & 278 & 92 \\
\hline \multirow[t]{5}{*}{ Tipulidae } & Tipula (Nobilotipula) nobilis (Loew) & 0.17 & 8 & 4 \\
\hline & Tipula (Savtshenkia) sp.1 & 0.37 & 68 & 16 \\
\hline & Tipula (Trichotipula) oropezoides Johnson & 0.03 & 2 & 2 \\
\hline & Tipula (Yamatotipula) iroquois Alexander & 0.03 & 1 & 1 \\
\hline & Tipula (Yamatotipula) cayuga Alexander & 0.03 & 1 & 1 \\
\hline \multicolumn{5}{|l|}{ Ephemeroptera } \\
\hline Leptophlebiidae & Paraleptophlebia debilis Eaton & 0.3 & 194 & 56 \\
\hline \multicolumn{5}{|l|}{ Plecoptera } \\
\hline Capniidae & Paracapnis angulata Hanson & 0.03 & 1 & 1 \\
\hline \multirow[t]{3}{*}{ Leuctridae } & Leuctra ferruginea Walker & 0.23 & 37 & 10 \\
\hline & Leuctra tenella Provancher & 0.07 & 18 & 10 \\
\hline & Paraleuctra sara Claassen & 0.13 & 11 & 3 \\
\hline \multirow[t]{4}{*}{ Nemouridae } & Nemoura ( Nemoura) trispinosa Claassen & 0.9 & 1664 & 429 \\
\hline & Nemoura (Ostrocerca) albidipennis Walker & 0.07 & 39 & 35 \\
\hline & Nemoura (Prostoia) completa Walker & 0.03 & 11 & 11 \\
\hline & Nemoura (Soyedina) vallicularia $\mathrm{Wu}$ & 0.77 & 182 & 49 \\
\hline Chloroperlidae & Alloperla mediana Banks & 0.2 & 31 & 17 \\
\hline \multicolumn{5}{|l|}{ Trichoptera } \\
\hline Hydroptilidae & Hydroptila sp.1 & 0.03 & 1 & 1 \\
\hline \multirow[t]{5}{*}{ Lepidostomatidae } & Lepidostomatidae $n$.det.1 & 0.1 & 7 & 4 \\
\hline & Lepidostoma sp.1 & 0.9 & 1102 & 299 \\
\hline & Lepidostoma sp.2 & 0.4 & 426 & 66 \\
\hline & Lepidostoma sp.3 & 0.3 & 96 & 24 \\
\hline & Lepidostoma sp.4 & 0.3 & 95 & 19 \\
\hline \multirow[t]{12}{*}{ Limnephilidae } & Hesperophylax designatus (Walker) & 0.27 & 31 & 19 \\
\hline & Limnephilidae $n$.det. 1 & 0.5 & 119 & 24 \\
\hline & Limnephilidae $n$.det.2 & 0.03 & 5 & 5 \\
\hline & Limnephilidae $n$.det. 3 & 0.17 & 23 & 9 \\
\hline & Limnephilidae $n$.det. 4 & 0.03 & 1 & 1 \\
\hline & Limnephilidae $n$. det.5 & 0.03 & 2 & 2 \\
\hline & Limnephilidae $n$.det. 6 & 0.03 & 2 & 2 \\
\hline & Limnephilidae $n$.det. 7 & 0.2 & 50 & 23 \\
\hline & Limnephilidae $n$.det. 8 & 0.17 & 27 & 14 \\
\hline & Limnephilidae $n$.det.9 & 0.13 & 16 & 8 \\
\hline & Limnephilidae $n$.det. 10 & 0.03 & 2 & 2 \\
\hline & Limnephilidae $n$.det. 11 & 0.03 & 1 & 1 \\
\hline Molannidae & Molanna blenda Sibley & 0.03 & 1 & 1 \\
\hline
\end{tabular}


only $51 \%$ of the species total after three years were recorded during the first (1996) season.

Table 3. Cumulative number of species collected at sites E1, E3, and $\mathrm{O} 8$ during the period from 1996-8 (numbers in brackets are percent total for that site).

\begin{tabular}{llllllll}
\hline Site & \multicolumn{2}{c}{1996} & \multicolumn{3}{c}{$\begin{array}{c}\text { Year } \\
\text { 1997 }\end{array}$} \\
\hline E1 & 8 & & $(42)$ & 15 & & \multicolumn{2}{c}{1998} \\
E3 & 12 & $(59)$ & 16 & & 19 & $(100)$ \\
O8 & 27 & $(60)$ & 42 & $(93)$ & 45 & $(100)$ \\
\hline
\end{tabular}

\section{Species richness}

Because of the strong dependency of the total number of species sampled on the duration of the sampling period, the analyses concerned with comparing species composition among sites in this and the following section were based on the longest sampling duration common to all sites (14 sampling months). Figure 5 compares the numbers of species among sites, broken down into the contributions made by individual taxonomic groups. The plot shows, firstly, that the total number of species collected varied dramatically among sites, ranging from 4 at site A2 to 27 at site O8. Secondly, although the highest proportion of species at most sites was comprised of Limoniidae, that taxon had fewer individuals than Trichoptera and Plecoptera at sites A1, E1, and E6, and was absent at sites A2 and B1.

\section{Species-environment relationships}

In the first analysis run, with all environmental variables, mean temperature and mean conductivity proved to be highly collinear. In a second run, with mean conductivity removed from the environmental dataset, no further collinearities were found (Fig. 6). Species positioned close to the origin, were assumed to have had little weight in the overall ordination result (Jongman et al. 1987) and were omitted from the plot for better readability. Judging by the inter-set correlations of the environmental variables with the canonical axes (Table 4), the first axis is mainly associated with temperature (both mean temperature [mtemp], increasing to the left, and temperature variability [vtemp], increasing to the right), and mean $\mathrm{pH}$ (increasing to the left). Since, as noted earlier, mean annual temperature at the surveyed spring sites was strongly correlated with geographical location, the first axis also reflected a northsouth gradient with the northernmost group of sites (O1-O9) to the right and the southernmost group (E1E7) to the left. The second axis is best interpreted as a mean discharge gradient, separating with few exceptions, the low-discharge helocrenes (in the top half of the plot) from the high-discharge rheo- and limnocrenes (in the bottom half of the plot). By interpreting the position of each of the species in terms of environmental factors associated with the two CCA axes, we can designate characteristic species to each of the four main factor combinations expressed in the four quadrants of the biplot:

- Temperate, high-flow conditions (lower left quadrant): chiefly caddisflies (many of the limnephilids, e.g. Hesperophylax designatus, and two of the four Lepidostoma species), the plecopteran Nemoura vallicularia, and the empidid Chelifera caligae;

- Temperate, low-flow conditions (upper left quadrant) almost exclusively limoniids, most prominently Pedicia contermina and Paradelphomyia pleuralis;

- Cold, low-flow conditions (upper right quadrant): mixed groups, most notably the plecopterans Nemoura albidpennis and Leuctra ferruginea, the ptychopterid Ptychoptera rufocincta, and the limoniid Erioptera megaphthalma;

- Cold, high-flow conditions (lower right quadrant): only a few species, such as the ephemeropteran Paraleptophlebia debilis and the trichopteran Lepidostoma sp.4.

In addition to chironomids, limoniids are clearly a dominant faunistic element in the helocrenes of the survey. This agrees with what little information is available about the larval biology of the recorded limoniid species, which are reported to inhabit soft sediments in semi-aquatic habitats (F. Brodo, pers. comm.). However, the fact that limoniid species were recorded from all but two sites in this study suggests that the group as a whole may have a larger ecological role than was previously thought. For instance, many species of the carnivorous genus Dicranota, which includes the, by far, most abundant and widespread species in the survey, Dicranota flaveola, are predominantly found burrowing in well-oxygenated banks of coarse sand which are typical of larger rheocrenes.

The second most diverse insect group in the survey, the Trichoptera, generally preferred the 'classical' rheo- and limnocrene sites. Characterization of the limnephilid Hesperophylax designatus as a typical inhabitant of rheocrenes, for example, agrees with the findings of other studies conducted in coldwater springs across Canada (e.g., Williams \& Williams 1987).

Regression of number of species against mean spring discharge (a proxy estimation of spring habitat 
(a) E1
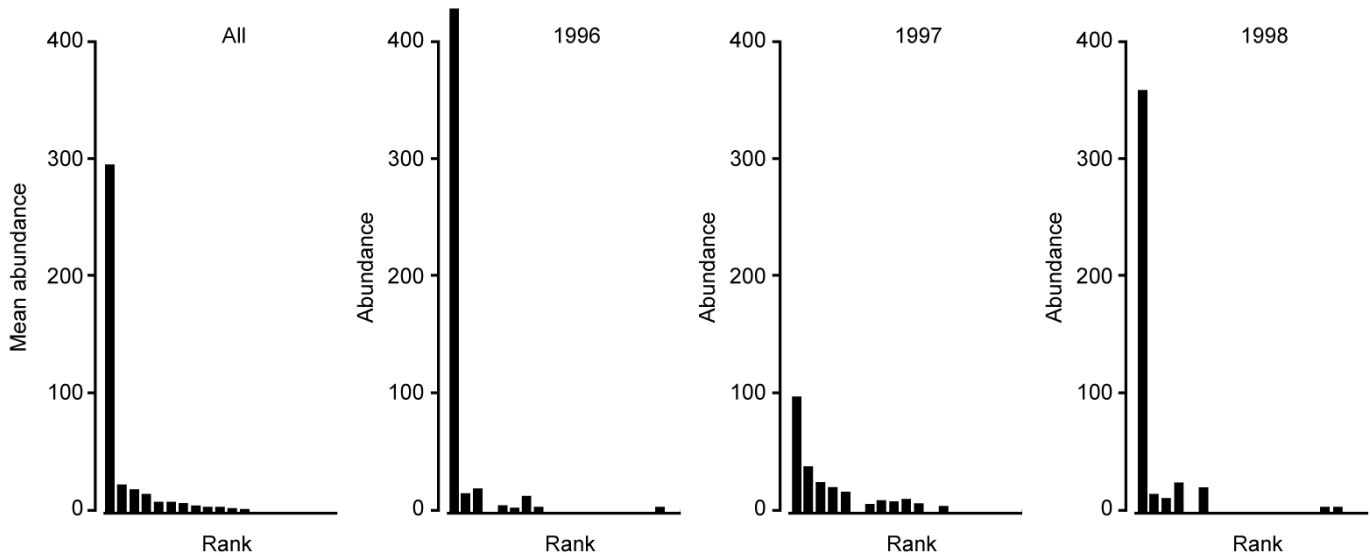

(b) E3
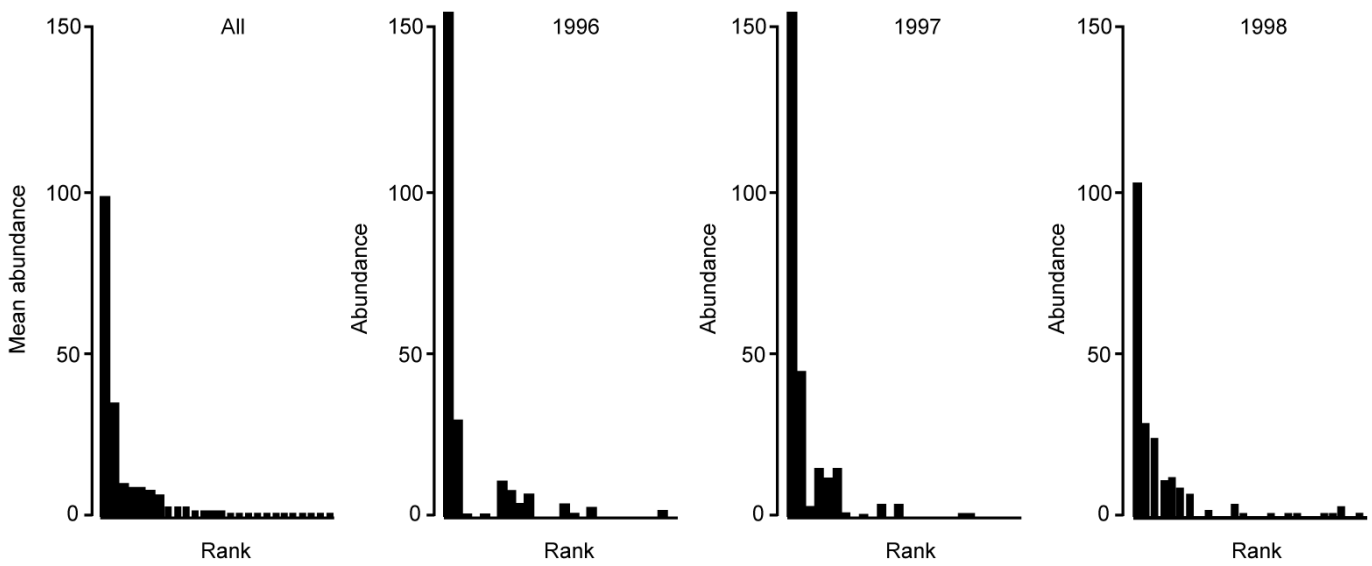

(c) 08
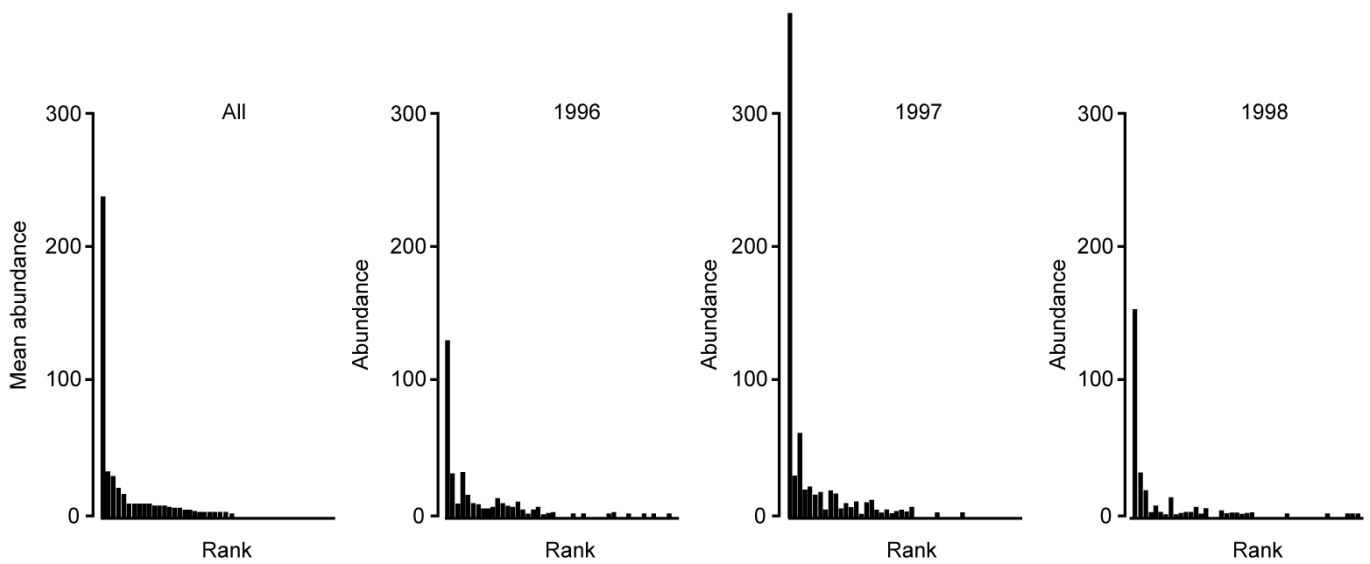

Fig. 4. Rank-abundance plots of all taxa (except Chironomidae n.det.) from sites E1, E3, and O8 for the three study years 1996, 1997 , and 1998. The ranks are based on averaged abundances for all years shown in the left-hand plots. 


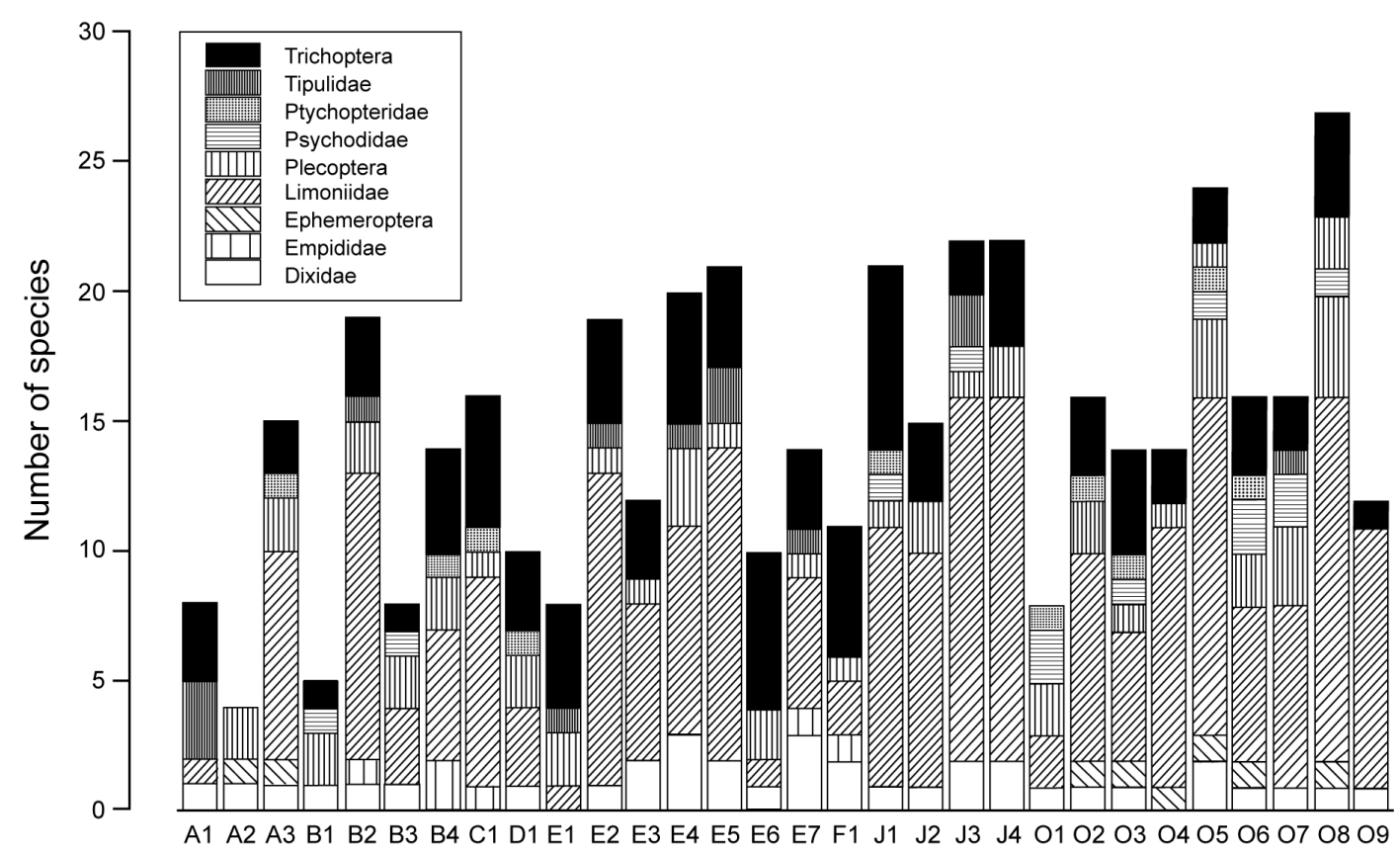

Fig. 5. Number of species collected per spring per taxonomic group. Springs

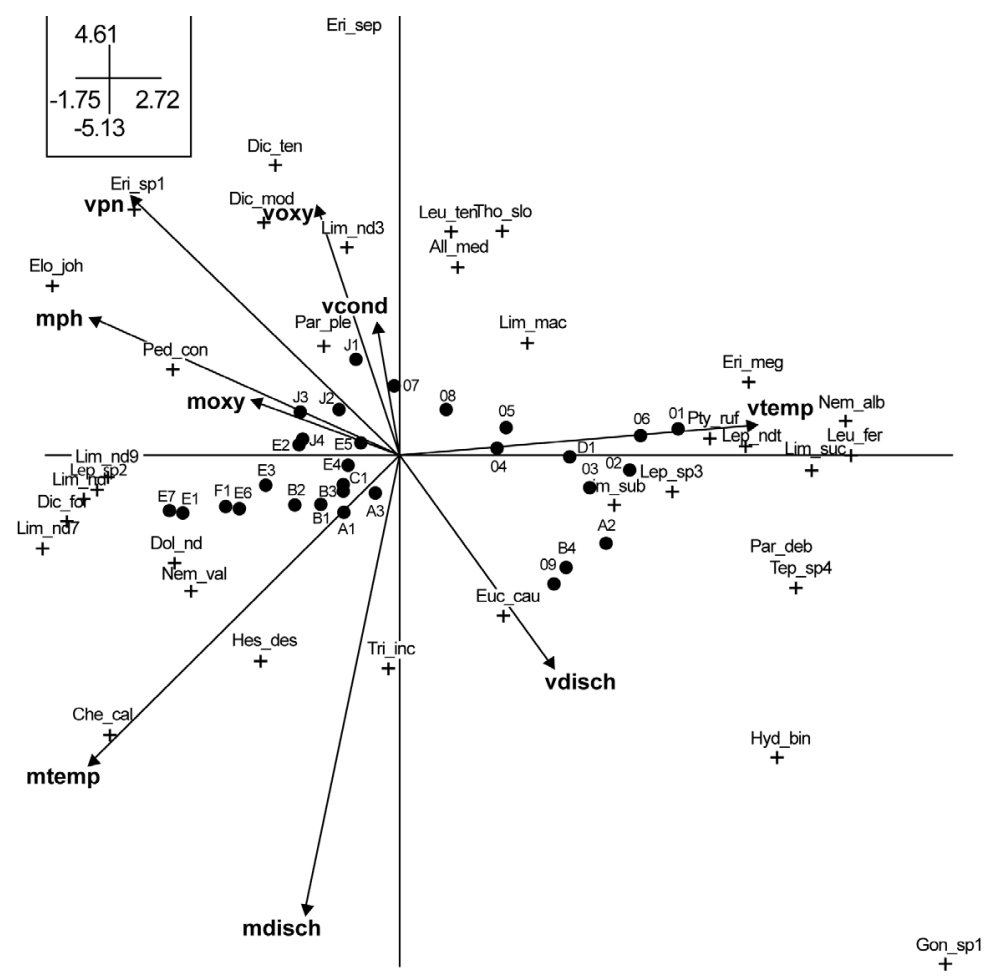

Fig. 6. CCA plot of emergence data in principal scaling (sensu Greenacre, 1984). Symbols indicate sites (black dots) and species (crosses), arrows indicate canonical variates. Species labels are derived from taxon names listed in Table 2. Canonical variate labels are composed of an " $\mathrm{m}$ " (mean value) or a "v" (coefficient of variation) plus a code for the environmental factor ("temp" for temperature, "disch" for discharge, "pH" for $\mathrm{pH}$, "cond" for conductivity, and "oxy" for oxygen saturation). Species placed within a radius of 1 unit around the origin are not shown. For further results, see Table 4. 
size) produced a surprisingly negative relationship $(\mathrm{r}=$ $-0.46 ; \mathrm{p}=0.01 ; \mathrm{n}=30$ ), explaining $21 \%$ of the variance in the data.

Table 4. CCA results. The first nine rows are the inter-set correlations of environmental variables with axes. The last three rows are species/environment correlations, eigenvalues, and percent of variance explained by axis, respectively.

\begin{tabular}{lcccc}
\hline Variable & Axis 1 & Axis 2 & Axis 3 & Axis 4 \\
\hline mtemp & -0.4345 & -0.3841 & 0.3151 & 0.0451 \\
mph & -0.4288 & 0.1727 & 0.0431 & 0.4647 \\
moxy & -0.1966 & 0.0718 & 0.2618 & 0.2976 \\
vtemp & 0.5036 & 0.0426 & -0.3759 & -0.3082 \\
vdisch & 0.2168 & -0.2561 & -0.5644 & -0.3987 \\
vph & -0.3760 & 0.3228 & -0.4526 & 0.1431 \\
voxy & -0.1140 & 0.3101 & -0.4983 & -0.4230 \\
veond & -0.0294 & 0.1648 & -0.4639 & -0.2102 \\
mdisch & -0.1278 & -0.5695 & 0.4264 & 0.1283 \\
spec./env. & 0.9188 & 0.9136 & 0.8876 & 0.8758 \\
eigenvalues & 0.3531 & 0.2045 & 0.1883 & 0.1392 \\
\% var. expl. & 27 & 16 & 14 & 11 \\
\hline
\end{tabular}

\section{Discussion}

The species richness observed for the various taxonomic groups in our study largely agree with results from similar studies in glaciated areas in Europe (e.g., Lindegaard et al. 1998), particularly the scarcity of Ephemeroptera and the high diversity of Limoniidae. Limoniids have rarely been reported explicitly (beyond the family level) from coldwater springs in North America (e.g., Anderson \& Anderson 1995), probably because of the lack of reliable identification keys; they are often reported as Tipulidae. Within our Ontario springs, the CCA showed that most limoniid species were found under temperate, low-flow conditions, although Erioptera megaphthalma, for example, was more associated with cold, low-flow conditions. Not all of the limoniid species recorded in this study are strictly crenobiotic, as some also occur in other freshwater habitats (F. Brodo, pers. comm.). For example, Limnophila fuscovaria and Neolimnomyia brevifurca were among more than 17 species of limoniid emerging from woodland floodplain habitats in southwestern Michigan (Merritt \& Lawson 1981). Nevertheless, this diverse and abundant group seems very well suited for characterizing the complex mosaic of microhabitats typically found in coldwater springs, and therefore warrants closer investigation.

Many studies have reported an increase in species richness downstream from a spring source (e.g., Sloan 1956, Minckley 1963, Ward \& Dufford 1979, but see Resh 1983 for an exception). This pattern is likely explained by the thermal constancy hypothesis (Ward \& Stanford 1982, 1983, see also Vannote \& Sweeney
1980), in which streams with more variable thermal regime allow more species to meet their developmental requirements than the comparatively constant thermal regime of springs. However, if thermal regime was the only factor determining overall species richness, then species richness from thermally less stable springs would be higher than from thermally constant sites. Yet, using the coefficient of variation of our temperature data, we found no indication of a relationship between thermal variability and overall species richness in the southern Ontario spring data set. Most likely, other factors in these springs, such as differences in water chemistry or hydraulic regime, are influential in determining species richness (McCabe 1998).

Little is known about how well emergence records from one year approximate the 'true' species richness at any given spring site. Long-term emergence records from a small stream in Germany showed that only the dominant species were reliably detected every year (e.g., Wagner \& Gathmann 1997). For springs, results from the present study point towards a similar conclusion (Fig. 4), but with an important additional implication. Springs may be regarded as habitat islands in a hostile environment for all crenobiont and, to a lesser degree, crenophilous species. Because of the rather limited size of most springs, the absence of a particular species in the emergence record from a particular year may well reflect a preceding extinction of the local population rather than constitute a sampling error. Interestingly, Stagliano et al. (1998) recorded an average of only $25 \%$ of emerging insects returning to the water surface in a small wetland pond in the southeastern USA; the rest were presumed either to have been consumed by terrestrial predators or to have emigrated to other systems. Importantly, the percentage return varied significantly among species (e.g., close to $100 \%$ in the chironomids Dicrotendipes and Tanypus, but only around 6\% in the chironomid Ablabesmyia), so a scenario in which an emerging species fails to re-establish itself in the same small pond or spring in any given year seems plausible. Granted, there are still some methodological obstacles to be overcome in accurately quantifying 'return' data before we have a better understanding of local extinction patterns in such habitats.

It has to be acknowledged that a possible alternative explanation for inconsistency of species captured in emergence traps in coldwater springs is that some species may be very slow-growing in their larval stages and thus may not emerge to adulthood every year. For example, the life cycle of the caddisfly Sericostoma personatum in Danish springs has been recorded as ta- 
king different times to complete and hence adults to emerge: 2 years in Fonstrup Baek (temperature range $\left.0.5-20.5^{\circ} \mathrm{C}\right)$, and 3 years in Rold Kilde $\left(2.4-13.6^{\circ} \mathrm{C}\right)$ (Iversen 1980). However, further support for the local extinction theory comes from Nurnberger's (1996) two year study of the local dynamics and dispersal of the gyrinid beetle, Dineutus assimilis. Within an area of 60 $\mathrm{km}^{2}$, populations occurred in 31 of 51 ponds but varied dramatically between years, including nine extinction events. Nine colonization events were also recorded, showing the species to be a highly successful colonizer of newly available sites. Dispersal distances, determined from marked individuals, ranged from $100 \mathrm{~m}$ to at least $20 \mathrm{~km}$, and typically occurred following diapause. Interestingly, there was considerable variation in reproductive success, thought to be the result of local pond conditions, and immigration rates varied widely within a single season.

Despite comparison of springs to habitat islands, our dataset yielded a negative relationship between species richness and a proxy for habitat size (mean annual discharge). This appears to contradict the prediction of MacArthur \& Wilson's (1967) island biogeography theory, wherein larger springs would be expected to support more species. But perhaps mean annual discharge is a less reliable measure of spring habitat size, especially when a mixture of spring types (e.g., rheocrenes, limnocrenes, rheo-limnocreness, helocrenes) are being considered.

Recent studies have attempted to detect species-environment correlations in the coldwater springs of a particular region, ultimately aiming to establish an environmentally based regional spring typology (e.g., Germany, Braukmann 1987, and Great Britain, Furse et al. 1984, Wright et al. 1984). Success in defining such typological systems based on environmental factors has been quite variable. Verdonschot et al. (1996) distinguished several well-defined 'biotypes' in a diverse set of Dutch helocrenes based on spring habitat persistence (i.e., occurrence and extent of drought events) and acidity. Zollhöfer \& Olten (1996) presented a typological system for springs of the Jura Region and the Mittelland in Switzerland, using a combination of physiological and hydrogeological factors. Similarly, Gerecke et al. (1998) reported well-defined temporal-permanent and rheocrene-helocrene gradients in microinvertebrate communities from 19 springs in the Alps of Berchtesgaden, Germany. On the other hand, macroinvertebrate communities from 19 springs in the Rhön highlands, also in Germany, showed no correlations with environmental factors other than habitat persistence (Gathmann 1994). In the large survey of $110 \mathrm{Da}-$ nish springs conducted by Lindegaard et al. (1998), the presence or absence of a springbrook was the only factor to correlate significantly with macroinvertebrate community composition.

The results of the present study are somewhat ambiguous with respect to the prospects of deriving an environmental typology for southern Ontario springs. Although the broad pattern of faunal similarity among the study sites correlated well with major environmental parameters, namely, the temperature and discharge regimes, the ordination results also showed a clear tendency to group together spatially adjacent sites (e.g., O1-09). This 'neighborhood effect', which has also been reported from German (Gathmann 1994) and southern Romanian (Gathmann et al. unpublished data) springs, indicates that spatial adjacency of spring sites might be an important factor determining overall community similarity. For the present study, this is somewhat unexpected, as the individual sites in each spatial site group were specifically chosen to reflect the whole locally available spectrum of physiographic spring types.

Assuming that coldwater springs constitute habitat islands for a significant fraction of their inhabitants (see above), Gathmann (1994) suggested an explanation for this phenomenon in terms of repeated cycles of extinctions and recolonizations (i.e., metapopulation dynamics) in at least some of the local populations; however, this hypothesis awaits further corroboration. Should the latter prove true, it brings up the interesting question of the continuity of function of coldwater spring ecosystems. If the magnitude of species change from one year to the next, as suggested from this study, is representative of these small systems in general, then the relative strengths of, for example, their trophic and bioturbation (Solan et al. 2004) processes may well fluctuate, perhaps affecting local wetland/watershed conditions.

\section{Acknowledgement}

This study was supported by a HSP-II-AUFE scholarship of the DAAD, Germany, the Schmeil Stiftung, Germany, and the Natural Sciences and Engineering Research Council of Canada. The authors wish to thank Prof. Rüdiger Wagner, Schlitz, Germany, for identification of the Dixidae, Empididae, and Psychodidae; Dr. Fenja Brodo, Nepean, Ontario, for identification of the Limoniidae; Prof. Harold Atwood, University of Toronto, for granting access to springs on his property; and Annie Khan and Lucie Sliva for technical assistance.

\section{References}

Anderson T.M. \& Anderson N.H. 1995. - The insect fauna of spring habitats in semiarid rangelands in central Oregon. J. Kansas Entomol. Soc., 68, 65-76. 
Botosaneanu L. (ed) 1998. - Studies in crenobiology. Backhuys, Leiden, $261 \mathrm{p}$.

Braukmann U. 1987. - Zoozönologische und saprobiologische Beiträge zu einer allgemeinen regionalen Bachtypologie. Arch. Hydrobiol., Suppl., 26, 1-317.

Colbo M.H. 1991. - A comparison of the spring-inhabiting genera of Chironomidae from the Holarctic with those from natural and man-made springs in Labrador, Canada. Mem. Entomol. Soc. Can., 155, 169-179.

Danks H.V. \& Williams D.D. 1991. - Arthropods of springs, with particular reference to Canada: synthesis and needs for research. Mem. Entomol. Soc. Can., 155, 203-217.

Deane R.E. 1950. - Pleistocene geology of the Lake Simcoe District, Ontario. Mem. Geol. Surv. Can., 256, 1-108.

Erman N.A. 1998. - Invertebrate richness and Trichoptera phenology in Sierra Nevada (California, USA) cold springs: sources of variation. Pages 95-108 in Studies in crenobiology. Botosaneanu L. (ed). Backhuys, Leiden.

Erman N.A. \& Erman D.C. 1995. - Spring permanence, trichopteran species richness, and the role of drought. J. Kansas Entomol. Soc., Suppl., 68, 50-64.

Ferrington L.C. 1995. - Biodiversity of aquatic insects and other invertebrates in springs. J. Kansas Entomol. Soc., Suppl., 68, 165.

Fischer J., Fischer F., Schnabel S., Wagner R. \& Bohle H. 1998. Die Quellfauna der hessischen Mittelgebirgsregion. Besiedlungsstruktur, Anpassungsmechanismen und Habitatbindung der Makroinvertebraten am Beispiel von Quellen aus dem Rheinischen Schiefergebirge und der osthess. Buntsandsteinlandschaft. Pages 183-199 in Studies in crenobiology. Botosaneanu L. (ed). Backhuys, Leiden.

Furse M.T., Moss D., Wright J.F. \& Armitage P.D. 1984. - The influence of seasonal and taxonomic factors on the ordination and classification of running-water sites in Great Britain and on the prediction of their macroinvertebrate communities. Freshwat. Biol., 14, 257-280.

Gathmann F.O. 1994. - Faunistische und zoozönologische untersuchungen an quellen der Rhön. Masters Thesis, Philipps Univ. Marburg, Germany.

Gathmann F.O. 2000. - Pydas; the Python Data Analysis Servant. User's manual and reference library. Ph.D. Thesis, Univ. Toronto, Canada.

Gerecke R., Meisch C., Stoch F., Acri F. \& Franz H. 1998. - Eucrenon/Hypocrenon ecotone and spring typology in the Alps of Berchtesgaden (Upper Bavaria, Germany). A study of microcrustacea (Crustacea: Copepoda, Ostracoda) and water mites (Acari: Halacarida, Hydrachnellae). Pages 167-182 in Studies in crenobiology. Botosaneanu L. (ed). Backhuys, Leiden.

Glazier D.S. 1998. - Springs as model systems for ecology and evolutionary biology: a case study of Gammarus minus Say (Amphipoda) in mid-Appalachian springs differing in $\mathrm{pH}$ and ionic content. Pages 49-62 in Studies in crenobiology. Botosaneanu L. (ed). Backhuys, Leiden.

Gore J.A. 1996. - Discharge measurements and streamflow analysis. Pages 53-74 in Methods in stream ecology. Hauer, R.F. \& Lamberti, G.A. (eds). Academic Press, San Diego.

Greenacre M.J. 1984. - Theory and applications of Correspondence Analysis. Academic Press, London, $364 \mathrm{p}$

Illies J. 1971. - Emergenz 1969 im breitenbach. Arch. Hydrobiol., 69, 14-59.

Iversen T.M. 1980. - Densities and energetics of two streamliving larval populations of Sericostoma personatum (Trichoptera). Holarct. Ecol., 3, 65-73.

Iversen T.M. 1988. - Secondary production and trophic relationships in a spring invertebrate community. Limnol. Oceanogr., 33, 582-
592.

Jongman R.H., ter Braak C.J.F. \& van Tongeren O.F.R. 1987. - Data analysis in community and landscape ecology. Pudoc, Wageningen.

Kamp G. 1995. - The hydrogeology of springs in relation to the biodiversity of spring fauna: a review. J. Kansas Entomol. Soc., Suppl., 68, 4-17.

Liberty B.A. 1969. - Palaeozoic geology of the Lake Simcoe area, Ontario. Depart. Energy, Mines and Resources, Ottawa.

Lindegaard C., Brodersen K.P., Wiberg-Larsen P. \& Skriver J. 1998. - Multivariate analyses of macrofaunal communities in Danish springs and springbrooks. Pages 201-219 in Studies in crenobiology. Botosaneanu L. (ed). Backhuys, Leiden.

MacArthur R.H. \& Wilson E. 1967. - The equilibrium theory of island biogeography. Princeton University Press, New Jersey.

McCabe D.J. 1998. - Biological communities in springbrooks. Pages 221-228 in Studies in crenobiology. Botosaneanu L. (ed). Backhuys, Leiden.

Merritt R.W. \& Lawson D.L. 1981. - Adult emergence patterns and species distribution and abundance of Tipulidae in three woodland floodplains. Environ. Entomol., 10, 915-921.

Minckley W.L. 1963. - The ecology of a spring stream, Doe Run, Meade County, Kentucky. Wildl. Monogr., 11, 1-24.

Mundie J. H. 1956. - Emergence traps for aquatic insects. Mitt. Int. Ver. Angew. Limnol., 7, 113.

Nielsen A. 1950. - On the zoogeography of springs. Hydrobiologia, 2, 313-321.

Nurnberger B. 1996. - Local dynamics and dispersal in a structured population of the whirlygig beetle Dineutus assimilis. Oecologia, 106, 325-336.

Odum E.P. 1971. - Fundamentals of ecology. Saunders, Toronto.

Odum H.T. 1957. - Trophic structure and productivity of Silver Springs, Florida. Ecol. Monogr., 27, 55-112.

Resh V.H. 1983. - Spatial differences in the distribution of benthic macroinvertebrates along a springbrook. Aquat. Insects, 5, 193200.

Roughley R.E. \& Larson D.J. 1991. - Aquatic Coleoptera of springs in Canada. Mem. ent. Soc. Can., 155, 125-140.

Sloan W.C. 1956. - The distribution of aquatic insects in two Florida springs. Ecology, 37, 81-98.

Solan M., Cardinale B.J., Downing A.L., Engelhardt K.A., Ruesink J.L. \& Srivastava D.S. 2004. - Extinction and ecosystem function in the marine benthos. Science, 306, 1177-1180.

Stagliano D.M., Benke A.C. \& Anderson D.H. 1998. - Emergence of aquatic insects from two habitats in a small wetland pond in the southeastern USA: temporal patterns of numbers and biomass. J. N. Amer. Benthol. Soc., 17, 37-53.

STORM Coalition 1997. - Oak Ridges Moraine. Boston Mills Press, Erindale, Ontario.

Teal, J.M. 1957. - Community metabolism in a temperate cold spring. Ecol. Monogr., 27, 283-302.

ter Braak C.J.F. 1986. - Canonical correspondence analysis: a new eigenvector technique for multivariate direct gradient analysis. Ecology, 67, 1167-1179.

Tilly L.J. 1968. - The structure and dynamics of cone spring. Ecol. Monogr., 38, 169-197.

van Everdingen R.O. 1991. - Physical, chemical, and distributional aspects of Canadian springs. Mem. Ent. Soc. Can., 155, 7-28.

Vannote R.L. \& Sweeney B.W. 1980. - Geographic analysis of thermal equilibria: a conceptual model for evaluating the effect of natural and modified thermal regimes on insect communities. Amer. Nat., 115, 667-691.

Verdonschot P.F.M., Schot J.A. \& Mosterdijk H.G. 1996. - Monitoring springs in the northern and central part of the province Limburg; situation and global characterization. Water Board Peel en 
Maasvallei and Water Purification Board Limburg/Institute for Forestry and Nature Research, Report 251. $181 \mathrm{pp}$.

Wagner R., Fischer J. \& Schnabel S. 1998. - The Dipteran community of Central European springs: a summary. Pages 157-165 in Studies in crenobiology. Botosaneanu L. (ed). Backhuys, Leiden.

Wagner R. \& Gathmann F.O. 1997. - Long-term studies on aquatic dance-flies (Diptera, Empididae) 1983-1993, distribution and size patterns along the stream, abundance change between years and the influence of environmental factors on the community. Arch. Hydrobiol., 137, 385-410.

Ward J.V. \& Dufford R.G. 1979. - Longitudinal and seasonal distribution of macroinvertebrates and epilithic algae in a Colorado springbrook-pond system. Arch. Hydrobiol., 86, 284-321.

Ward J.V. \& Stanford J.A. 1982. - Thermal responses in the evolutionary ecology of aquatic insects. Ann. Rev. Entomol., 27, 97117.

Ward J.V. \& Stanford J.A. 1983. - The intermediate-disturbance hypothesis. An explanation for biotic diversity patterns in lotic ecosystems. Pages 347-356 in Dynamics of lotic ecosystems. T.D. Fontaine T.D. \& Bartell S.M. (eds). Ann Arbor Science, Ann Ar- bor, Michigan.

Williams D.D. \& Danks H.V. 1991. - Arthopods of springs: introduction. Mem. ent. Soc. Can. 155, 3-5.

Williams D.D. \& Williams N.E. 1987. - Trichoptera from cold freshwater springs in Canada: records and comments. Proc. Entomol. Soc. Ontario, 118, 13-23.

Williams D.D. \& Williams N.E. 1998. - Invertebrate communities from freshwater springs: what can they contribute to pure and applied ecology? Pages 251-261 in Studies in crenobiology. Botosaneanu L. (ed). Backhuys, Leiden.

Williams N.E. 1991. - Geographical and environmental patterns in caddisfly (Trichoptera) assemblages from cold-water springs in Canada. Mem. ent. Soc. Can., 155, 107-124.

Wright J.F., Moss D., Armitage P.D. \& Furse M.T. 1984. - A preliminary classification of running-water sites in Great Britain based on macroinvertebrate species and the prediction of community type using environmental data. Freshwat. Biol., 14, 221-256.

Zollhöfer J.M. \& Olten C.-H. 1996. - Regionale Quelltypologie für Jura und Mittelland in der Schweiz. Crunoecia, 5, 265-280. 